\title{
RÉDEI MÁRIA: DEMOGRÁFIAI ISMERETEK
}

\author{
(REG-INFO Kft., Budapest, 2006, 248 o.) \\ BERÉNYI B. ESZTER
}

Rédei Mária „Demográfiai ismeretek” címú, legújabb könyve azzal a nem titkolt céllal készuilt egyetemi oktatást segítendő tankönyvnek, melyre címe is utal, hogy ismereteket adjon. Hiánypótlónak mondható ez a könyv két szempontból is. Egyrészröl jelentek meg már a Szerzỏ által írt hasonló témájú könyvek, azok azonban nem oktatási segédletként készuiltek. Másrészröl pedig szinte alig van olyan átfogó munka, amely a demográfiai folyamatokat globális és lokális nézópontból is megkỏzelíti, azokat a gazdasági viszonyokkal is összehasonlítja, valamint részletesen elemzi a magyarországi és új elemként a budapesti folyamatokat.

A könyv tizenegy fejezetböl áll, melyet részletes irodalomjegyzék egészít ki, amely segíti a téma iránt érdeklódő diákokat az egyes résztémákban való elmélyülésben. Ugyanezt a célt szolgálja a „Függelék”, amely enciklopédiaszerủen - bár néha talán kissé terjengősen - összefoglalja a könyv által használt fontosabb alapfogalmakat, így azoknak könnyen utána tud nézni az olvasó, vagy éppen az okulni vágyó diák. Szintén a könnyebb kereshetőséget segíti a „Táblázatok és Ábrák jegyzéke”, amely nagyon hasznos a könyv tanulmányozása során. A tanulást segítik elő a fejezetek végén található „Kérdések, feladatok" rovat is. Sajnos ez a roppant hasznos segédlet a könyv végén található fejezeteknél elmaradt, amely a fejezetek tartalmával magyarázható. Ezen fejezetek ugyanis jövőbeli trendeket vázolnak fel, amelyek nem annyira tényszerủ megállapítások, hanem inkább előrejelzések. Ezek ugyanakkor roppant értékes fejezetei a könyvnek, hiszen felvázolják a várható demográfiai folyamatokat és azok gazdasági, politikai konzekvenciáit. Az oktatás szempontjából pedig elengedhetetlen ez a fajta nézópont, hiszen - mint ahogyan az a „Bevezető gondolatokban” is megtalálható - elsősorban a földrajz, geográfus szakosok számára készült ez a könyv, akik a késöbbiekben a terület- és településfejlesztés területén fognak dolgozni. Az egyes fejezeteket igen gazdag és sok esetben újszerú ábraanyag egészíti ki. Az ábrákat amellett, hogy jól illusztrálják a szöveget - részletesen elemzi is a Szerző, amely nagyban segíti a folyamatoknak, ill. maguknak az ábrának a megértését.

Tematikáját tekintve a második és harmadik fejezet szorosan összefügg: a demográfia alapfogalmaival, módszereivel, forrásaival foglalkozik. Részletesen bemutatásra és magyarázásra kerülnek az alapvetỏ fogalmak, problémák - amelyek a tanítási problémákra is kiterjednek -, valamint a kutatás során felhasználható adatok, adatbázisok, ill. az azok által nyerhető egyéb információk és összefüggések is.

A negyedik és ötödik fejezet - az elözỏ kettőhöz hasonlóan - szintén szoros kapcsolatban van. A negyedik fejezet ugyanis részletesen tárgyalja a népesség megoszlásával kapcsolatos főbb elméleti jellemzőket, azokat pedig az ötödik fejezet során 
részletesen elemzi. Az elemzés globális és magyarországi szinten történik, de a Szerző kitér a belső regionális jellemzökre is.

A hatodik fejezet tartalmát tekintve a népesedés egyéb eseményeivel (pl. születés, halálozás, szegregáció) foglalkozik, és ugyanúgy tartalmaz területi szintủ elemzést, mint az ötödik fejezet. Talán éppen ezért tagolódhatna ez a fejezet akár két kisebb fejezetre is. A fejezet kiemelt témaköre a nemzetközi migráció.

Kizárólag a hazai viszonyokat írja le a következö két fejezet (hetedik, nyolcadik), azonban két nézöpontból és két területi szinten. A hetedik fejezet az ország népesedési viszonyainak következő húsz évre történő elöreszámításával foglalkozik, ezen belül a munkaerőpiaci jellemzökre fekteti a hangsúlyt. A nyolcadik fejezet Budapestet helyezi a középpontba, mint hazánk meghatározó városát. Ennek nagy jelentösége van abból a szempontból, hogy átfogó és szintetizáló demográfiai jellegú vizsgálat nem készült Budapestről az elmúlt években.

A kilencedik fejezet a népesség-elöreszámítás kérdéskörére koncentrál, lépésrỏllépésre végigvezetve egy konkrét példát. A tizedik fejezet pedig a tudományos eredmények felhasználhatóságát tárgyalja a politikai, ill. gazdasági szféra szemszögéből. 